\title{
Uji Resistensi Bakteri Pseudomonas Sp. yang Disolasi dari Plak Gigi terhadap Merkuri
}

\author{
${ }^{1}$ Stella M. Sutanto \\ ${ }^{2}$ Billy J. Kepel \\ ${ }^{2}$ Widdhi Bodhi
}
${ }^{1}$ Program Studi Pendidikan Dokter Fakultas Kedokteran Universitas Sam Ratulangi Manado ${ }^{2}$ Bagian Kimia Fakultas Kedokteran Universitas Sam Ratulangi Manado
Email: ssutanto_11_171@yahoo.com

\begin{abstract}
Mercury is a highly toxic element for all living creatures either in the form of single element or compound. In human bodies, there are a lot of bacteria that are resistance to mercury and antibiotics such as trimethoprim. It is reported that Pseudomonas sp. can detoxify mercury. This study was aimed to evaluate the resistance of Pseudomonas sp. isolated from tooth plaques to mercury $\left(\mathrm{HgCl}_{2}\right)$. This was a descriptive explorative study. The results showed growth of bacterium colonies in the media containing mercury with concentrations of $10 \mathrm{ppm}, 20 \mathrm{ppm}$, and $40 \mathrm{ppm}$, but not with the concentration of $80 \mathrm{ppm}$. Conclusion: Pseudomonas sp. isolated from tooth plaques were resistant to mercury $\left(\mathrm{HgCl}_{2}\right)$ but not to concentration of $80 \mathrm{ppm}$.
\end{abstract}

Keywords: mercury, dental plaque, Pseudomonas sp.

\begin{abstract}
Abstrak: Merkuri merupakan unsur yang sangat beracun bagi semua makhluk hidup baik dalam unsur tunggal maupun persenyawaan. Tubuh manusia memiliki banyak bakteri yang resisten terhadap merkuri dan trimetoprim, seperti halnya bakteri Pseudomonas sp. yang dapat mendetoksifikasi merkuri. Penelitian ini bertujuan untuk menguji resistensi bakteri Pseudomonas sp. yang disolasi pada plak gigi terhadap merkuri. Jenis penelitian ialah deskriptif eksploratif. Hasil penelitian mendapatkan pertumbuhan koloni bakteri pada konsentrasi $\mathrm{HgCl}_{2} 10 \mathrm{ppm}, 20 \mathrm{ppm}$, dan $40 \mathrm{ppm}$, sedangkan pada $80 \mathrm{ppm}$ tidak terdapat pertumbuhan. Simpulan: Pseudomonas sp. yang diisolasi dari plak gigi telah resisten terhadap merkuri $\mathrm{HgCl}_{2}$ kecuali pada konsentrasi $80 \mathrm{ppm}$.
\end{abstract}

Kata kunci: merkuri, trimetoprim, plak gigi, Pseudomonas sp.

Berbagai jenis bakteri saat ini semakin cerdik menghancurkan kerja antibiotic yang berakibat semakin banyak bakteri yang meningkat kekebalannya. ${ }^{1} \quad$ Oleh karena itu untuk meningkatkan keberhasilan pengobatan dengan antibiotik perlu dilakukan uji resistensi bakteri.

Merkuri merupakan unsur yang sangat beracun bagi semua makhluk hidup baik dalam bentuk unsur tunggal maupun senyawa. Keberadaannya di alam hanya dalam konsentrasi yang relatif rendah yaitu sekitar 1ng/l. Secara umum terdapat tiga bentuk merkuri, yaitu unsur merkuri $\left(\mathrm{Hg}^{0}\right)$, merkuri anorganik $\left(\mathrm{Hg}^{2+}\right.$ dan $\left.\mathrm{Hg}_{2}{ }^{2+}\right)$, dan merkuri organik $\left(\mathrm{R}-\mathrm{HG}^{+}, \mathrm{RHgR}\right){ }^{2}$

Penggunaan merkuri sangat luas dalam berbagai aspek kehidupan manusia. Terdapat sekitar 3.000 jenis kegunaan merkuri antara lain dalam industri pengolahan bahan-bahan kimia, proses pembuatan obat-obatan yang digunakan oleh manusia, serta sebagai bahan dasar pembuatan insektisida dalam pertanian. ${ }^{3}$

Tubuh manusia memiliki banyak bakteri yang resisten terhadap merkuri 
seperti halnya bakteri Pseudomonas $s p .^{3}$ Keracunan anorganik $\mathrm{Hg}$ sudah dikenal sejak abad ke-18 dan ke-19 dengan gejala tremor pada orang dewasa yang disebut hatter's shakes (topi bergoyang), karena pada saat itu banyak pekerja di pabrik topi dan wol menderita gejala tersebut. ${ }^{4}$

Plak gigi adalah suatu lapisan lunak terdiri atas kumpulan bakteri yang berkembang biak di atas suatu matriks, terbentuk dan melekat erat pada permukaan gigi yang tidak dibersihkan, yang merupakan salah satu faktor terjadinya proses karies dan inflamasi jaringan lunak. Lokasi pembentukan plak pada permukaan gigi diklasifikasikan atas plak supragingival berada pada atau koronal dari tepi gingiva dan plak subgingival berada pada apikal dari tepi gingiva. Plak supra dan subgingiva hampir tiga perempat bagian terdiri atas berbagai macam bakteri Gram positif dan Gramnegatif, termasuk bakteri fakultatif anaerob dan obligat anaerob. ${ }^{3}$

Dari hasil penelitian-penelitian sebelumnya, mikroba jenis tertentu terutama bakteri dapat mendetoksifikasi merkuri. Mekanisme detoksifikasi logam berat oleh mikroba berlangsung sangat kompleks yang meliputi presipitasi dan kristalisasi logam berat yang terjadi pada bagian ekstrasel dan intrasel mikroba. Beberapa jenis bakteri yang telah diketahui dapat menjadi resisten terhadap merkuri yaitu bakteri aerobik dan fakultatif yang mengatalisis proses reduksi $\mathrm{Hg}$ (II) menjadi $\mathrm{Hg}(0)$ seperti bakteri jenis Bacillus, Pseudomonas, Corynebacterium, Micrococcus, dan Vibrio. Reduksi oleh bakteri tersebut dapat digunakan sebagai strategi remediasi untuk endapan terkontaminasi. ${ }^{5}$

\section{METODE PENELITIAN}

Jenis penelitian ini ialah deskriptif eksploratif dan dilakukan pada bulan November 2014 sampai Desember 2014 di Laboratorium Mikrobiologi Farmasi Fakultas MIPA Universitas Sam Ratulangi.

Populasi penelitian ini ialah semua bakteri yang tumbuh pada plak gigi yang ada di Laboratorium Mikrobiologi Farmasi Fakultas MIPA Universitas Sam Ratulangi
Manado. Sampel penelitian ini ialah bakteri Pseudomonas sp pada plak gigi yang telah diisolasi resisten terhadap merkuri yang tumbuh pada media Luria Bertani (LB) broth dan media LB padat.

Bakteri resisten merkuri adalah jenis bakteri yang dapat bertahan hidup pada media kultur merkuri klorida $\left(\mathrm{HgCl}_{2}\right)$ dengan konsentrasi 10 ppm, 20 ppm, 40 ppm, dan 80 ppm.

\section{Prosedur Kerja}

Pada uji resistensi merkuri koloni Pseudomonas ditumbuhkan pada media LB broth dengan menggunakan jarum ose yang sudah mengandung merkuri, kemudian dipindahkan pada media agar miring dengan menggunakan jarum ose sebagai kultur sediaan (antibiotik dan resisten merkuri), diinkubasi pada suhu $37^{\circ} \mathrm{C}$ selama 24 jam, dan disimpan pada suhu $4^{\circ} \mathrm{C}$, kemudian dilakukan kembali inokulasi kultur bakteri Pseudomonas $S p$ dalam media $\mathrm{LB}$ broth yang mengandung $\mathrm{HgCl}_{2}$ dalam beberapa konsentrasi yang berbeda yaitu 10 ppm, 20 ppm, 40 ppm, dan 80 ppm. Diamati jumlah koloni yang tumbuh.

\section{HASIL PENELITIAN}

Pengamatan uji resistensi merkuri dilakukan terhadap bakteri Pseudomonas $s p$ yang diambil dari hasil isolat yang sudah diidentifikasi dan dilaksanakan pada bulan November sampai bulan Desember 2014 di Laboratorium Mikrobiologi Farmasi, Program Studi Farmasi, Fakultas MIPA Universitas Sam Ratulangi Manado.

Uji resistensi terhadap merkuri $\left(\mathrm{HgCL}_{2}\right)$ menggunakan media Luria Bertani broth (LB broth) terhadap masingmasing konsentrasi. Bakteri Pseudomonas $s p$. diletakkan pada 4 media LB Broth dengan konsentrasi merkuri $\mathrm{HgCl}_{2}$ yang berbeda, yaitu 10 ppm, 20 ppm, 40 ppm, dan 80 ppm. Berdasarkan hasil penelitian yang telah dilakukan, pada konsentrasi $\mathrm{HgCl}_{2} 10$ ppm didapatkan pertumbuhan banyak dari bakteri isolat dan pertumbuhan berlangsung masih cepat dengan melihat warna kekeruhan pada media LB broth. Pada konsentrasi $\mathrm{HgCl}_{2} 20$ ppm didapatkan 
pertumbuhan sedang dari bakteri isolat dan pertumbuhan bakteri sudah mulai lambat. Pertumbuhan bakteri hanya sedikit pada media dengan konsentrasi $\mathrm{HgCl}_{2} 40$ ppm, dan tidak terdapat pertumbuhan atau mati pada media dengan konsentrasi $\mathrm{HgCl}_{2} 80$ ppm.

Tabel 1. Uji resistensi merkuri terhadap bakteri Pseudomonas sp

\begin{tabular}{ccl}
\hline Media (Ag) di LB broth & Pertumbuhan & \multicolumn{1}{c}{ Keterangan } \\
\hline $10 \mathrm{ppm}$ & + & Pertumbuhan bakteri banyak \\
$20 \mathrm{ppm}$ & + & Pertumbuhan bakteri sedang \\
$40 \mathrm{ppm}$ & + & Pertumbuahan bakteri sedikit \\
$80 \mathrm{ppm}$ & - & Tidak ada pertumbuhan \\
\hline
\end{tabular}

\section{BAHASAN}

Uji resistensi terhadap merkuri dilakukan pada media LB broth dengan menggunakan metode gores. Bakteri Pseudomonas $s p$ ditumbuhkan dalam tabung reaksi yang berisi media LB broth dengan menggunakan konsentrasi merkuri $\left(\mathrm{HgCl}_{2}\right)$ yang berbeda-beda yaitu $10 \mathrm{ppm}, 20 \mathrm{ppm}, 40$ ppm dan 80 ppm. Uji resistensi merkuri ini bertujuan untuk melihat konsentrasi kemampuan bakteri dapat tumbuh.

Hasil penelitian menunjukkan pada merkuri $\left(\mathrm{HgCl}_{2}\right)$ konsentrasi 10 ppm terjadi pertumbuhan lebih cepat dari pada merkuri $\left(\mathrm{HgCl}_{2}\right)$ konsentrasi $20 \mathrm{ppm}$ yang terlihat dengan warna keruh pada media LB broth. Pada merkuri $\left(\mathrm{HgCl}_{2}\right)$ konsentrasi $20 \mathrm{ppm}$ pertumbuhan bakteri lebih cepat daripada merkuri $\left(\mathrm{HgCl}_{2}\right)$ konsentrasi 40 ppm, sedangkan pada merkuri $\left(\mathrm{HgCl}_{2}\right)$ konsentrasi 80 ppm sudah tidak terdapat pertumbuhan bakteri. Hal ini berarti bakteri Pseudomonas sp sensitif terhadap merkuri pada konsentrasi tinggi. Pada merkuri $\left(\mathrm{HgCl}_{2}\right)$ konsentrasi $40 \mathrm{ppm}$ yang tumbuh pada media LB broth dapat disebabkan oleh: pertama, bakteri resisten terhadap merkuri dengan tingkat ketahanan merkuri yang cukup tinggi; kedua, adanya plasmid yang mengandung gen resisten merkuri yang masuk ke dalam sel. Hasil uji resistensi Pseudomonas terhadap merkuri $\left(\mathrm{HgCl}_{2}\right)$ menunjukkan bahwa konsentrasi merkuri $\left(\mathrm{HgCl}_{2}\right)$ sangat berpengaruh. Kultur bakteri Pseudomonas sp. pada merkuri konsentrasi $40 \mathrm{ppm}$ dan $80 \mathrm{ppm}$ menunjukkan resistensi terhadap merkuri lebih rendah dibandingkan dengan terhadap merkuri konsentrasi $10 \mathrm{ppm}$ dan $20 \mathrm{ppm}$. Diduga kerja merkuri konsentrai 40 ppm dan 80 ppm terhadap bakteri Pseudomonas $s p$ dengan cara pertama yaitu menghambat metabolisme sel sehingga terjadi pertumbuhan yang lambat atau mati. Pada penggunaan merkuri konsentrasi $10 \mathrm{ppm}$, 20 ppm dan 40 ppm, diduga Pseudomonas sp. mengandung gen resisten merkuri spektrum sempit dimana mer penentu resisten hanya terjadi pada garam merkuri organik saja yang berbeda dengan mer penentu resisten spektrum luas yang resisten terhadap metilmerkuri dan fenilmerkuri, serta garam merkuri anorganik.

Pseudomonas sp. dapat mengubah diri sedemikian rupa sehingga dapat mengurangi efektifitas dari suatu jenis obat, bahan kimia, atau zat lainnya. Akibatnya bakteri tesebut tetap dapat bertahan hidup dan bereproduksi sehingga makin membahayakan. Hal ini didukung oleh penelitian sebelumnya yang dilakukan Prambudi dan Zuraida mengenai kepekaan antibiotik terhadap Pseudomonas aeroginosa penyebab sepsis neonatorum, yang mendapatkan lebih dari $70 \%$ bakteri penyebab ialah Gram negatif, Pseudomonas aeroginosa $(44 \%){ }^{6}$

\section{SIMPULAN}

Dari hasil penelitian ini dapat disimpulkan bahwa Pseudomonas sp. yang diisolasi dari plak gigi telah resisten terhadap merkuri $\mathrm{HgCl}_{2}$ kecuali pada konsentrasi 80 ppm. 
DAFTAR PUSTAKA

1. Andarsini MR, Ugrasena IDG, Permono B. Antibiotic resistance control program in pediatric hematology and oncology patients at Dr. Soetomo Hospital in 2006-2007. IJTID. 2010;1(2):90-92.

2. Hammond PB, Beliles RP, editors. Toxicology - the Basic Science of Poisons. New York: Macmillan, 1980; p 409-67.

3. Prasetyawati ET. Bakteri rhizosfer sebagai pereduksi merkuri dan agensia hayati.
Surabaya: UPN Press, 2009.

4. Freeman JA. Mercurial disease among hatters. Transactions, Medical Society of N. J. 1860; p. 61-4.

5. Alfian Z. Merkuri: antara manfaat dan efek penggunaannya bagi kesehatan manusia dan lingkungan. Medan: USU e-Repository, 2006; p. 2.

6. Rukmono P, Zuraida R. Uji kepekaan antibiotik terhadap pseudomonas aeroginosa penyebab sepsis neonaterum. Sari Pediatri. 2013;14(5):332-6. 